\title{
DISTRIBUSI ZAKAT DAN PEMBERDAYAAN EKONOMI UMAT
}

\author{
Mubasirun \\ Dosen Jur. Syari'ah Sekolah Tinggi Agama Islam Negeri (STAIN) Salatiga \\ mubasirun55@yaboo.com
}

\begin{abstract}
Zakat in Central Java is estimated to reach Rp 9,356 trillion each year, derived from zakat, infak and sedekah (ZIS) Rp 8,982 trillion and Rp 374.275 billion zakat fitrah. This is derived from the assumption that most Moslem give ZIS Rp.1 million each year. The purpose of this research is informing the meaning of zakat as recited in Surah Attaubah verse 60, how the zakat was distributed and observing the effectiveness of zakat in the relation with economic empowerment. Techniques in analyzing the data were domain, taxonomy, components and theme analysis. The finding showed that zakat distribution was dominated by consumption distribution. On the other hands productive distribution was not regards. But it is interesting to be noticed that distribution of zakat funds committed by the institutions of zakat distribution pattern dominated by the cost living in various pattern of their varieties While distribution patterns that rely on productive among the educated (scholars) are ignored by board of charity.
\end{abstract}

Key words: Zakat, Distribution, Empowerment.

\begin{abstract}
Abstrak
Zakat di Jawa Tenga h diperkirakan mencapai Rp. 9.365 trilyun setiap tabunnya yang berasal dari Zakat, Infak dan Sedekah (ZIS) Rp. 8.982 trilyun dan Rp. 374.275 miyard zakat fitrah dengan asumsi babwa sebagian besar Muslim memberikan ZISsebesar 1 juta setiap tabunnya. Tujuan dalam artikel penelitian ini adalab untuk mengetahui bagaimana ragam penafsiran makna zakat dan sebagaimana yang termuat dalam surat at Taubah ayat 60, bagaimana seharusnya zakat itu didistribusikan kaitannya dengan upaya peningkatan kesejabteraan ekonomi umat, serta sejaub mana efektifitas zakat itu dalam peningkatan kesejabteraan ekonomi umat. Ada empat teknik analisis data yang akan digunakan dalam penelitian ini, yaitu ; (1) analisis domain, (2) analisis taksonomis, (3) analisis komponensial, dan (4) analisis tema. Hasil temuan menunjukkan babwa distribusi dana zakat yang dilakukan oleb lembaga-lembaga zakat didominasi pola distribusi kunsumtif melalui jalur biaya hidup dengan berbagai fareasinya. Sementara pola distribusi secara produktif yang diandalkan oleb kalangan terdidik (akademisi) masih terabaikan oleh lembag-lembaga zakat.
\end{abstract}

Kata kunci: Zakat, Distribusi, Pemberdayaan. 


\section{Pendahuluan}

Zakat, sebagai rukun Islam yang ketiga, merupakan instrumen utama dalam ajaran Islam yang berfungsi sebagai pemberdayaan dari tangan si kaya kepada si miskin. Ia merupakan institusi resmi yang diarahkan untuk menciptakan pemerataan dan pemberdayaan masyarakat, sehingga taraf kehidupan masyarakat dapat ditingkatkan. Al-Qur'an dalam surat at-Taubah ayat 103 menjelaskan bahwa zakat itu diambil dari orang-orang yang berkewajiban untuk berzakat ( $m u z a k k i$ ) untuk kemudian diberikan kepada golongan yang berhak menerimanya.

Peranan 'amil dalam pemberdayaan ekonomi masyarakat ini menjadi sangat penting, karena ia merupakan badan atau lembaga perantara antara muzakki sebagai subyek pemberdayaan dan mustahiqsebagai obyek pemberdayaan, walaupun pada prinsipnya muzakki dapat langsung menyerahkan zakatnya kepada mustahiq. Tetapi sebagaimana dijelaskan dalam Alquran surah at-Taubah: 103 bahwa zakat itu diambil dari orang-orang yang berkewajiban untuk berzakat (muzakki) untuk kemudian diberikan kepada mereka yang berhak menerimanya (mustahik). Yang mengambil dan yang menjemput tersebut adalah para petugas ('amil). Imam Qurthubi (Qarthubi: 1993; 112-113) ketika menafsirkan ayat 60 surah at-Taubah menyatakan bahwa 'amil itu adalah orang-orang yang ditugaskan (diutus oleh imam/pemerintah) untuk mengambil, menuliskan, menghitung dan mencatatkan zakat yang diambilnya dari para muzakki untuk kemudian diberikan kepada yang berhak menerimanya.

Mampu atau tidaknya zakat dapat memberdayakan ekonomi masyarakat sangat tergantung pada bagaimana sistem distribusi yang diterapkan. Distribusi zakat dapat dikategorikan kepada dua; secara konsumtif dan secara produktif. Secara konsumtif berarti harta zakat dibagikan langsung kepada mustabiq untuk dimanfaatkan secara konsumtif. Sementara harta zakat didistribusikan secara produktif berarti mustabiq tidak menerima harta zakat yang langsung dimanfaatkan untuk dikonsumsi tetapi harus diusahakan terlebih dahulu, baik oleh mustahiq sendiri maupun oleh lembaga amil, yang dikonsumsi adalah hasil dari usaha tersebut. 
Jawa Tengah merupakan daerah strategis bagi pengembangan sosial ekonomi dan sosial keagamaan dalam upaya memberdayakan ekonomi masyarakat. Data statistik menunjukkan jumlah penduduk Jateng 33,18 juta jiwa, jumlah rumah tangga miskin (RTM) 3,1 juta keluarga dari 6,7 juta rumah tangga (46,26\%). Jumlah rumah tangga prasejahtera 3.198.596 keluarga, dan penduduk miskin 12,66 juta jiwa. Untuk umat Islam jalan keluar bagi upaya pemberdayaan ekonomi masyarakat, salah satunya adalah memaksimalkan potensi zakat. Potensi zakat di Jateng diperkirakan mencapai Rp 9,356 triliun setiap tahun, berasal dari zakat infak dan sedekah (ZIS) Rp 8,982 triliun dan zakat fitrah Rp 374,275 miliar. Potensi di Jateng dihitung berdasarkan asumsi rata-rata sepertiga penduduk muslim Jateng memberikan ZIS sebesar Rp 1 juta per tahun. Meskipun perhitungan itu masih kasar, namun bisa memberikan gambaran besarnya dana untuk meningkatkan kesejahteraan masyarakat Jateng. Berdasarkan data Kantor Wilayah Kementerian Agama Jateng penerimaan zakat fitrah, zakat mal, infak dan sedekah dari 35 kabupten/kota di Jateng, tahun 2008, sebesar Rp 223,704 miliar. Rinciannya zakat fitrah Rp 198,837 miliar dan ZIS Rp 23,238 miliar (Harian Suara Merdeka: 2009).

Kenyataan di masyarakat masyarakat Jawa Tengah menunjukkan bahwa zakat belum dapat memiliki peran yang siknifikan dalam pemberdayaan ekonomi umat. Hal ini disebabkan masih beragamnya pendistribusian zakat. Sebagian masyarakat menyalurkan zakatnya langsung ke mustahiq, sebagian lainnya melalui lembaga atau badan amil zakat baik yang resmi sesuai UU maupun yang dibentuk oleh nazir-nazir masjid. Bukan hanya pola pendistribusian yang beragam tapi juga berkaitan dengan penafsiran terhadap golongan penerima zakat atau ashnaaf dan fungsi zakat. Hal ini karena berkaitan dengan pola pendistribusian tersebut. Keragaman pola pendistribusian zakat tersebut dapat dipengaruhi oleh penafsiran keagamaan tentang zakat yang berkembang serta tradisi sosial yang mengitarinya. Oleh karena itu, penelitian ini akan membicarakan tentang bagaimana ragam penafsiran tentang zakat berkenaan dengan fungsi dan golongan penerima zakat yang berkembang di Jawa Tengah, pola-pola pendistribusian zakat yang dilakukan oleh Lembaga Zakat di Jawa Tengah dan efektivitas 
pemberdayaan ekonomi dengan pola-pola pendistribusian zakat tersebut.

\section{Kebijakan Pemerintah Terhadap Lembaga Zakat}

Dalam Undang-undang RI nomor 38 tahun 1999 tentang pengelolaan zakat, pasal 3 disebutkan bahwa Pemerintah berkewajiban memberikan perlindungan, pembinaan dan pelayanan kepada muzakki, mustabiq dan amil zakat. Dalam penjelasannya disebutkan pula bahwa yang dimaksud dengan amil zakat ialah pengelola zakat yang diorganisasikan dalam suatu badan atau lembaga.

Dari pasal 3 tersebut dapat pahami bahwa pemerintah dengan segala perangkatnya baik secara ekonomi, sosial kemasyarakatan dan keagamaan yang tercermin dari semua instansi terkait yang dimilikinya, mempunyai kewajiban memberikan perlindungan dalam penyelenggaraan pengelolaan zakat secara umum yang berkaitan dengan masalah hak dan kewajiban dari para mustahik, muzakki dan amil zakat untuk berekspresi dalam penyelenggaraan zakat di Indonesia sesuai dengan ajaran Islam. Hal ini karena memang tidak dapat dihindari bahwa pelaksanaan zakat tidak dapat lepas dari adanya doktrin ajaran Islam yang dimasukkan dalam kategori ibadah yang berkenaan langsung dengan kehidupan sosial kemasyarakatan yakni ajaran tentang ta'awun (tolong-menolong).

Islam telah menjadikan zakat bukan hanya sebagai sumbangan wajib saja, melainkan sebagai sesuatu yang harus dikumpulkan dan ditrisbusikan oleh pemerintah. Penanganan zakat oleh pemerintah juga mengandung maksud agar distribusi zakat memiliki dampak pada peningkatan ekonomi umat. Menurut Rahman (1995) dengan jelas al-Qur'an menyatakan bahwa institusi zakat harus dibentuk, diorganisasikan dan dipelihara oleh pemegang kekuasaan. Menjaga institusi zakat dinyatakan sebagai salah satu sarana yang penting dan harus diambil untuk membangun negara Islam. Rahman (1995: 248-249) menyandarkan pendapatnya kepada beberapa ayat al-Qur'an surat al-Hajj ayat 41 (yaitu) orang-orang yang jika Kami tegubkan kedudukan mereka di muka bumi, niscaya mereka mendirikan sembahyang, 
"Allah telab menjanjikan kepada orang-orang di antara kamu yang beriman dan mengerjakan kebajiakn, bahwa Dia sunggub akan menjadikan mereka berkuasa di bumi sebagaimana Dia telah menjanjikan kepada orang-orang sebelum mereka berkuasa, dan sunggub Dia akan menegubkan bagi mereka dengan agama yang telah Dia ridlai. Dan Dia benar-benar mengubah ( keadaan) mereka, setelab berada dalam ketakutan menjadi aman sentosa. Mereka (tetap) menyembahKu dengan tidak menyekutukan-Ku dengan sesuatupun. Tetapi barang siapa (tetap) kafir setelah (janji) itu maka mereka itulab orang-orang yang fasik. Dan laksanakanlah shalat, tunaikanlah zakat, dan taatlab kepada Rasul (Muhammad) agar kamu diberi rahmat."

Menurut Rahman penggunaan ayat "aqiimuu al-shalab wa atuu al-zakat"menunjukkan bahwa istitusi zakat harus ditegakkan dan diorganisir oleh masyarakat dan bukan oleh perorangan. Tidak diragukan lagi, anggota masyarakat secara individu dapat mengerjakan shalat dan membayar zakat sebagaimana ditetapkan dalam al-Qur'an. Tegasnya perintah اتوا الزكاة bukan perintah menangani zakat, melainkan perintah membayar zakat.

Zakat merupakan kewajiban bagi orang-orang yang mampu dalam suatu masyarakat. Dengan demikian, harus ada penguasa yang mendorong pembayaran zakat, walaupun kewajiban membayar zakat merupakan kewajiban yang tidak dapat ditinggalkan sama sekali atas inisiatif individu. Oleh karena itu, kekuasaan untuk mengumpulkan zakat perlu dilakukan oleh pemerintah (Afzalur Rahman: 1995; 248-249).

Jika penguasa itu tidak adil dan tidak menggunakan dana zakat untuk mereka yang benar-benar berhak, muzakki boleh menolak membayar zakat kepadanya dan mempunyai hak untuk secara langsung menyalurkan dana zakatnya kepada yang berhak. Alasannya adalah bahwa nisab zakat itu sudah pasti, begitu pula mustahik atau orang yang berhak menerima zakat. Dengan menyalurkan zakat secara langsung kepada yang berhak menerimanya maka ia telah memenuhi tujuan umum zakat. Sementara menyerahkan zakat kepada penguasa yang tidak adil, justru akan membuat orang-orang yang berhak menerima zakat menjadi menderita (Mawardi; 2005 : 177). 
Meskipun demikian untuk jenis kewajiban financial lain yang menjadi sumber penerimaan negara tetap harus dibayar, kendati penguasanya tidak adil. Alasannya, lembaga pemerintah tidak bisa dielakkan eksistensinya, meskipun bisa jadi tidak adil.

Undang-undang tentang pengelolaan zakat merupakan bentuk keseriusan pemerintah dalam dalam penerapan zakat di masyarakat sangat dituntut sosialisasi demi tercapainya tujuan zakat itu sendiri. Karena jika pemerintah tidak serius dalam mengurus zakat, maka akan tersumbat penyaluran dana zakat dari muzakki kepada mustahik.

\section{Peran Badan Amil Zakat}

Di Indonesia setelah diundangkannya UU RI nomor 38 tahun 1999 tentang pengelolaan zakat disebutkan ada 3 lembaga yang terlibat dalam pengelolaan zakat yaitu ; Badan Amil Zakat Nasional (BAZNAS) atau Badan Amil Zakat Daerah (BAZDA) yang wilayah operasionalnya provinsi, kabupaten/ kota dan kecamatan, Lembaga Amil Zakat (LAZ) dan Unit Pengelola Zakat (UPZ). Sebelumnya hanya dikenal satu nama saja yaitu Badan Amil Zakat, Infak dan Sedekah (BAZIS).

Karena banyaknya nama lembaga zakat dalam Undang Undang RI Nomor 38 tahun 1999 tersebut maka diperlukan aturan main yang jelas mengenai kedudukan dari masing-masing lembaga zakat agar tidak jadi benturan kepentingan, khususnya yang menyangkut BAZNAS dan BAZDA baik tingkat provinsi, kabupaten/kota maupun kecamatan yang memiliki daerah operasional yang sama.

Dalam pasal 8 UU No.38 disebutkan bahwa pembentukan badan amil zakat dinyatakan mempunyai tugas pokok yaitu mengumpulkan, mendistribusikan dan mendayagunakan zakat sesuai dengan ketentuan syari'ah, yang mana secara organisasinya terdiri dari tiga unsur yaitu; 1) unsur pertimbangan, 2) unsur pengawas dan 3) unsur pelaksana sebagaimana termuat dalam paal 6 ayat 5 yang dalam penjelasannya disebutkan bahwa unsur pertimbangan dan unsur pengawas terdiri dari para ulama, kaum cendikia, tokoh masyarakat dan wakil pemerintah. Sementara unsur pelaksana terdiri atas unit administrasi, unit pengumpul, unit 
pendistribusian dan unit lainnya sesuai dengan kebutuhan. Untuk meningkatkan layanan kepada masyarakat, dapat dibentuk unit pengumpul zakat sesuai dengan kebutuhan instansi pemerintah dan swasta, baik dalam negeri maupun luar negeri.

\section{Paradikma Baru Distribusi Zakat Menuju Pemberdayaan Ekonomi Umat}

Guna mengarahkan distrbusi zakat yang tepat sasaran dan memiliki daya guna yang tinggi dalam pemberdayaan ekonomi umat serta mendeskripsikan kontruksi dan persepsi masyarakat zakat (zakka soceity) secara holistik, maka dibutuhkan suatu perspektif interkonektif yang tidak hanya dilihat dengan pendekatan seperti fiqh al-zakat, namun juga perlu mempertimbangkan aspek sejarah, aspek ekonomi, budaya, agama dan dinamika perspektif khas masyarakat tersebut.

Sebagian kaum fakir miskin adalah orang yang bekerja pada suatu profesi tertentu atau mempunyai bakat produksi tertentu, tetapi mereka kurang berdaya lantaran tidak memiliki alat atau sarana produksi atau profesi tersebut. Para ulama fikih membolehkan pemberian zakat kepada mereka untuk pembelian alat dan sarana bekerja yang keuntungannya dapat memenuhi kebutuhannya. Penjahit, tukang kayu, tukang bangunan tukang jagal hewan, atau ahli-ahli produksi dan pekerja lainnya diberi zakat untuk membeli alat produksinya atau bagian dalam produksinya yang dapat mencukupi kebutuhan hidup dalam waktu yang lama.

Zakat, di samping termasuk dalam kategori ibadah mahdlah, juga memiliki dimensi sosial-ekonomi. Dalam pemberdayaan masyarakat, zakat memiliki peranan yang sangat strategis. Begitu pentingnya peranan zakat ini, sehingga sebagian masyarakat merasa memiliki tanggung jawab untuk mengelola zakat. Karena itu, walaupun sudah ada UU yang mengaturnya masih ada di kalangan masyarakat yang beranggapan bahwa pengelolaan zakat tidak mesti diatur oleh pemerintah atau UU. Pola-pola pendistribusian zakat pun juga didasarkan oleh tanggung jawab ini.

Sistem distribusi zakat yang merupakan salah satu sarana pemberdayaan ekonomi umat, dapat dikategorikan kepada dua; 
secara konsumtif dan secara produktif. Secara konsumtif berarti harta zakat dibagikan langsung kepada mustahiq yang untuk dimanfaatkan secara konsumtif. Sementara harta zakat didistribusikan secara produktif berarti mustahiq tidak menerima harta zakat yang langsung dimanfaatkan untuk dikonsumsi tetapi harus diusahakan terlebih dahulu, baik oleh mustahiq sendiri maupun oleh lembaga amil, yang dikonsumsi adalah hasil dari usaha tersebut.

\section{Pendistribusian dana zakat yang bersifat konsumtif}

Bentuk distribusi dana zakat dapat dilakukan melalui 4 (empat) bentuk, yaitu bantuan biaya hidup, bantuan biaya pendidikan, bantuan kesehatan, bantuan da'i dan desa binaan.

\section{Bantuan biaya bidup}

Pendistribusian zakat untuk porsi bantuan biaya hidup dapat diarahkan kepada asnaf fakir-miskin yang berdasarkan pengamatan amil zakat terhadap kehidupan sehari-harinya memang membutuhkan bantuan biaya hidup. Dalam hal ini lembaga atau Badan Amil Zakat dapat melakukan kordinasi dengan tokoh-tokoh masyarakat seperti takmir masjid, ketua-ketua kelompok pengajian, para ketua RT untuk menginventarisir calon penerima bantuan biaya hidup dari lembaga/badan amil zakat. Atau lembaga amil zakat daat bekerja sama dengan pemerintah setempat seperti desa/ kelurahan untuk penetapan calon penerima bantuan biaya hidup dari amil zakat.

\section{Bantuan biaya pendidikan}

Distribusi dana zakat untuk bantuan biaya pendidikan dapat dilakukan misalnya dengan memberikan beasiswa kepada para siswa dari keluarga tidak mampu untuk meringankan beban para orang tuanya. Untuk memenuhi tartip administrasi lembaga/badan amil zakat dapat menetapkan persyaratan-persyaratan yang harus dipenuhi oleh para calon penerima beasiswa. 


\section{Bantuan biaya kesehatan}

Program bantuan biaya kesehatan dapat berupa santunan untuk kesehatan, pelayan medis, biaya kelahiran bagi keluarga kurang mampu. Untuk meningkatkan pelayanan di bidang kesehatan, bila memungkinkan lembaga/badan zakat dapat memprogramkan pengadaan mobil ambulan yang didanai dari dana zakat.

\section{Bantuan da'i}

Da'i merupakan salah satu bagian dari upaya penegakan agama (i'la'i kalimaatillab). Maka sudah sewajarnya kalau lembaga amil zakat ikut memikirkan kesejahteraan para da'i dengan mengalokasikan dana zakat untuk dislurkan kepada mereka. Saudara dapat memasukkan para da'i ke dalam kelompok ashnaf sabililah.

\section{Pendistribusian dana zakat yang bersifat produktif}

Pendistribusian dana zakat yang bersifat produktif dapat dilakukan dalam beberapa model seperti:

Pertama, model dengan sistem in kind, yakni dana zakat diberikan dalam bentuk alat-alat produksi yang dibutuhkan oleh mustahiq/ kaum ekonomi lemah yang ingin berproduksi, baik mereka yang baru mulai usahanya maupun yang telah berusaha untuk pengembangan usaha yang telah ada. Untuk lebih jelasnya Saudara perhatikan gambar alur di bawah ini;

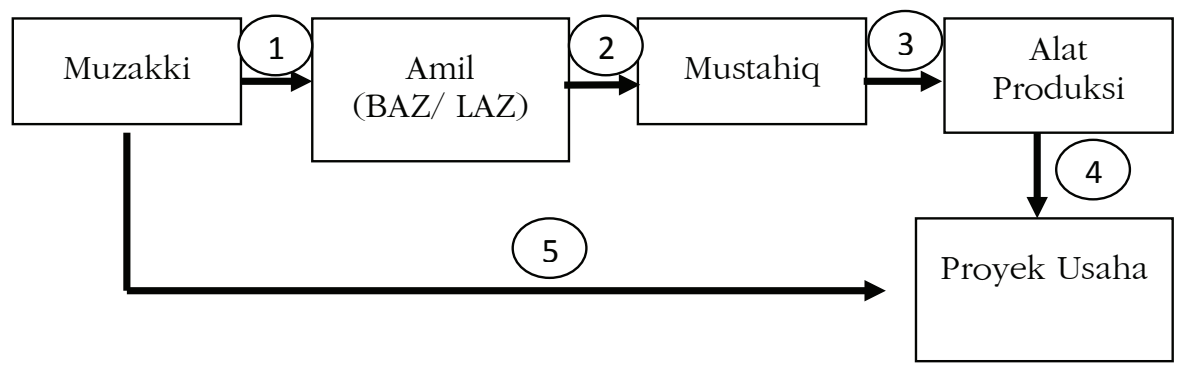

Sumber: Data terolah

Gambar 1

Sistem In Kind 
Keterangan;

1. Muzakki membayar zakat ke BAZ / LAZ

2. BAZ/LAZ menyalurkan kepada mustabiq(setelah studi kelayakan)

3. Dana zakat diberikan dalam bentuk alat-alat produksi

4. Mustahiq menggunakan alat-alat produksi untuk mengembangkan usahanya.

5. BAZ/LAZ melakukan pengawasan dan pembinaan terhadap proyek usaha mustahiq

Kedua, model sistem qardlul hasan, yakni peminjaman modal usaha dengan mengembalikan pokok tanpa ada tambahan jasa. Pokok pinjaman atau modal memang dikembalikan oleh mustabiq kepada lembaga amil zakat, namun tidak berarti bahwa modal itu tidak lagi menjadi hak mustabiq tersebut. Artinya modal masih dapat kembalikan lagi kepada mustahiq yang bersangkutan untuk dikembangkan lagi, atau bisa juga digulirkan ke mustabiq lain. Dengan cara ini diharapkan lembaga amil zakat dapat menjadi patner bagi para mustahiq untuk pengembangan usahanya sehingga secara pelan tapi pasti dapat mengubah statusnya dari mustabiq berubah menjadi muzakki. Untuk lebih jelasnya Saudara perhatikan gambar alur di bawah ini;

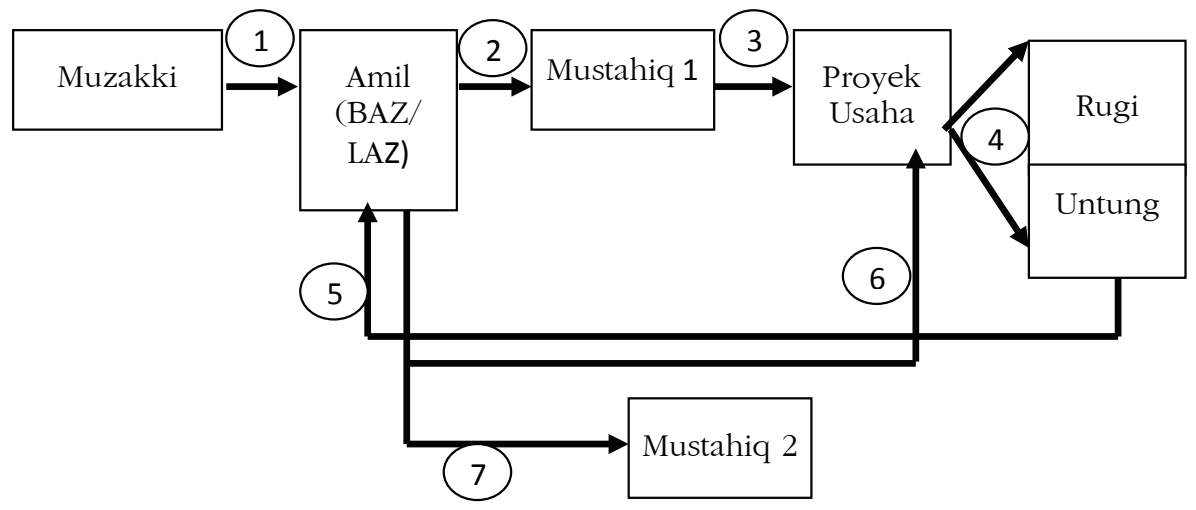

Sumber: Data terolah

Gambar 2

Model Sistem Qardlul Hasan 
Keterangan:

1. Muzakki membayar zakat ke BAZ / LAZ

2. BAZ/LAZ menyalurkan kepada mustabiq 1untuk modal usaha

3. Usaha rugi, mustabiq tidak perlu mengembalikan modal

4. Usaha untung, mustahiq mengembalikan modal kepada BAZ/LAZ

5. BAZ/LAZ menerima modal kembali dari mustahiq yang untung

6. BAZ/LAZ menyalurkan modal kembali kepada mustahiq untuk menambah modal

7. BAZ/LAZ menyalurkan modal kembali kepada mustahiq 2 untuk dimanfaatkan sebagai modal usaha dan begitu seterusnya.

Ketiga mudlarabah yakni penanaman modal usaha dengan konsekuensi bagi hasil. Sistem ini hampir sama dengan sistem qardlul hasan. Bedanya terletak pada pembagian bagi hasil dari usaha antara mustahiq dan amil. Untuk lebih jelasnya Saudara perhatikan gambar alur di bawah ini;

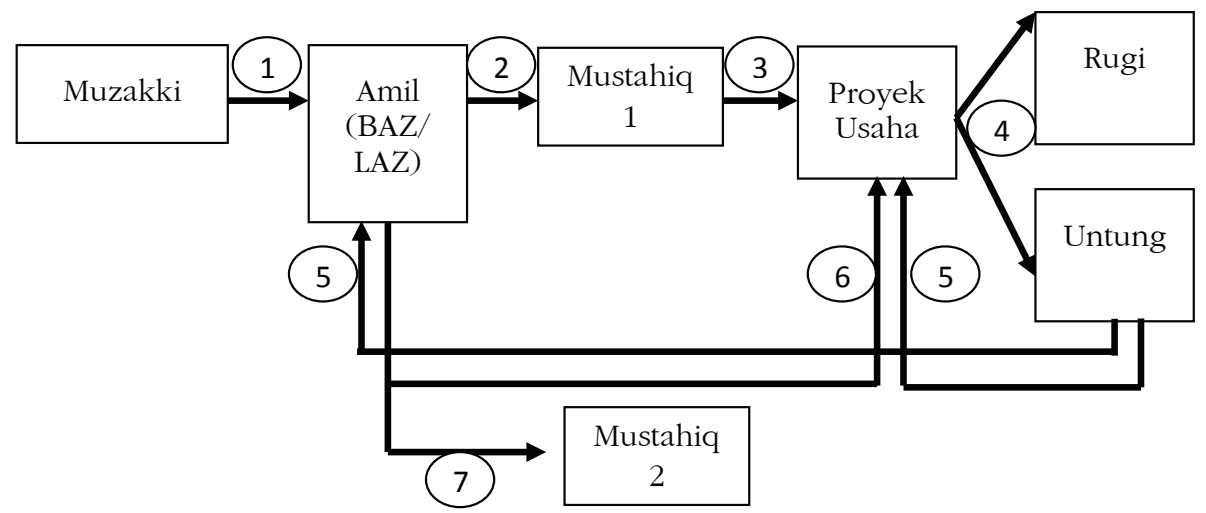

Sumber: Data terolah

Gambar 3

Mudlarabah 
Keterangan:

1. Muzakki membayar zakat ke BAZ / LAZ

2. BAZ/LAZ menyalurkan kepada mustabiq1untuk modal usaha

3. Usaha untung, saling bagi keuntungan, mustahiq mengambil sejumlah prosentase keuntungan dan selebihnya dikembalikan ke BAZ/LAZ berikut modalnya.

4. BAZ/LAZ menerima modal kembali sekaligus prosentase keuntungan usaha.

5. BAZ/LAZ memilih menyalurkan modal kembali kepada mustahiq untuk menambah modal

6. BAZ/LAZ memilih menyalurkan modal kembali kepada mustahiq 2 untuk dimanfaatkan sebagai modal usaha dan begitu seterusnya.

7. Jika usaha rugi, mustahiq tidak perlu mengembalikan modal.

Pendistribusian dalam bentuk investasi dapat dilakukan misalnya dengan ikut menanamkan saham di badan-badan usaha.

\section{Metode Penelitian}

Ada empat teknik analisis data yang akan digunakan dalam penelitian ini, yaitu ; (1) analisis domain, (2) analisis taksonomis, (3) analisis komponensial, dan (4) analisis tema. Ketiga analisis data yang disebutkan pertama dilakukan secara simultan di saat pengumpulan data di lapangan (analisis domain dipergunakan pada tahap eksplorasi menyeluruh, sedangkan analisis taksonomis dan komponensial dipergunakan pada tahap eksplorasi terfokus). Analisis data yang disebutkan terakhir (analisis tema) dilakukan setelah kegiatan pengumpulan dan analisis data di lapangan.

\section{Analisis}

\section{Pola Distribusi Zakat}

Berdasarkan temuan di lapangan menunjukkan adanya perbedaan antara lembaga zakat dan panitia zakat yang dibentuk oleh masjid-masjid. Lembaga amil zakat banyak menghimpun dana 
zakat mal, infak dan sedekah, sedangkan panitia zakat di masjidmasjid berkonsentrasi pada pengumpulan zakat fithrah, meskipun menampung juga zakat mal, akan tetapi jumlahnya tidak seberapa, dan itupun tidak melalui perhitungan secara profesional sesuai dengan ketentuan-ketentuan syari'ah yang ada. Perbedaan yang lainnya, para petugas di lembaga zakat pro aktif mendatangi para pembayar zakat ke rumah-rumah, seperti yang dilakukan para petugas zakat di LAZIM Salatiga yang melakukan pemungutan zakat dan infak dari para pembayar zakat di rumah-rumah setiap bulan, dan para petugas zakat di Bapelurzam melakukan pemungutan zakat setiap mendekati bulan Syawal. Sementara petugas di panitia zakat di masjid cukup menunggu para pembayar zakat di pos-pos kepanitiaan yang kebanyakan mengambil tempat di masjid-masjid.

Pola pendistribusian dana zakat dan infak dilihat dari sisi menejerial dapat digolongkan menjadi dua. Pertama, dana zakat diditribusikan dengan perencanaan yang matang, yang didahulaui dengan pendataan para calon mustahiq di lapangan. Hal yang seperti ini biasa dilakukukan pada lembaga-lembaga zakat, seperti yang dilakukan oleh lembaga zakat LAZIM, BAPELURZAM, dan masjid-masjid yang memiliki petugas-petugas yang trampil dan terdidik.Panitia zakat di Masjid Shuufi yang mengkoordinir beberapa panitia zakat tingkat mushalla yang menjadi domain, yang mendistribusikan harta pengumpulan zakat selalu didahului dengan koordinasi pendataan calon mustahiq. Kedua, dana zakat dan infak didistribusikan dengan tanpa perencanaan yang matang dan baik. Umumnya terjadi pada panitia zakat di masjid-masjid yang tidak memiliki tenaga-tenaga terampil dan terdidik.

Bila dilihat dari aspek kemanfaatannya, berdasarkan temuan di lapangan maupun data-data dokumen yang penulis dapatkan, dapat digolongkan menjadi dua. Pertama, pendistribusian yang bersifat konsumtif, yaitu pendistribusian zakat yang pemanfaatannya langsung digunakan oleh mustabiq dan habis dalam jangka pendek serta pendayagunaannya tidak menimbulkan pengaruh secara ekonomi dan pemberdayaan mustahiq. Kedua, pendistribusian harta zakat yang bersifat produkti, yaitu pendistribusian zakat yang pemanfaatannya tidak langsung habis tetapi pendayagunaannya dapat menimbulkan pengaruh secara ekonomi dan pemberdayaan mustahiq. 


\section{Pendistribusian Dana Zakat Yang Bersifat Konsumtif}

Bentuk distribusi dana zakat dilakukan dalam 4 (empat) bentuk, yaitu bantuan biaya hidup, bantuan biaya penddidikan, bantuan kesehatan, bantuan da'i dan desa binaan.

\section{Bantuan Biaya Hidup}

Semua lembaga amil zakat yang diteliti mempunyai progam ini. Lembaga ammil dalam pendistribusian dana zakat, dikumpulkan panitia zakat di masjid-masjid yang didominasi jenis zakat fithrah untuk semua asnaf, disalurkan dalam bentuk bantuan biaya hidup dalam wujud beras dan uang. Sementara dana zakat yang dikumpulkan oleh lembaga-lembaga zakat, bantuan biaya hidup disalurkan dalam bentuk uang. Hal ini disebabkan lembaga-lembaga zakat menghimpun dana zakat mal, infak dan sedekah, sedang dana zakat fithrah hanya sebagian kecil saja.

LAZIM pada periode September 2008 - Juli 2009 memyalurkan biaya hidup sejumlah Rp. 6.690.000,00 (6.5 \%). BAZ kota Salatiga pada tahun 2009 menyalurkan biaya hidup sebesar Rp. 165.000.000,00 (64.6\%) dengan perincian 50.000.000,00 untuk fakir miskin dari tenaga honorer di lingkungan Pemkot Salatiga dan 15.500.000,00 untuk guru TPQ se kota Salatiga sejumlah 155 orang.

BAZIS Kabupaten Semarang tahun 2010 menyalurkan biaya hidup Rp. 200.000.000,00 kepada 2000 guru honorer yang berada di wilayah kabupaten Semarang perorang Rp. 100.000,00. Di samping itu BAZIS Kabupaten Semarang juga menyalurkan dana ZISnya kepada para penggali kubur perorang Rp. 75.000,00, untuk tahun 2009 tercatat sejumlah Rp 3.750.000,00 untuk 50 orang penggali kubur. Selain itu BAZIS Kabupaten Semarang menyalurkan dana ZIZ nya kepada pera yatim piatu di berbagai panti asuhan yang tersebar di wilayah Kabupaten Semarang. Tahun 2009 tercatat 400 yatim piatu dari 84 panti asuhan a Rp 50.000,00, sehingga total dana ZIS yang dikeluarkan untuk yatim piatu 4200.000,00. Di samping itu juga tercatat 300 orang guru TPQ mendapat santunan masing-masing Rp. 75.000,00 (total Rp. 22.500.000,00) dan 300 warga miskin juga mendapat santunan a Rp 75.000,00 (total Rp 22.500.000,00) Total yang disalurkan untuk biaya hidup mencapai Rp 295.450.000,00 (76 \%) BAPELURZAM di tahun 2006 penyaluran biaya hidup (kelompok 
asnaf fakir-miskin) sebesar Rp.20.100.000,00 ( 27\%).

\section{Bantuan Biaya Pendidikan}

Berdasarkan temuan di lapangan, semua lembaga amil zakat yang diteliti memiliki program bantuan biaya pendidikan. lembaga amil zakat "LZIM" yang keberadaannya di bawah naungan Pimpinan Daerah Muhammadiyah Kota Salatiga, BAPELURZAM dan BAZIZ Kabupaten Semarang melaksanakan program bantuan biaya pendidikan dalam bentuk beasiswa mulai dari tingkat SD/ MI, SMP/MTs, SMA/MA dan Perguruan Tinggi (PT). LAZIM pada periode September 2008- Juli 2009 penyaluran dana ZIS untuk biaya pendidikan sejumlah Rp. 72.151.500,00 (70 \%)Bazis Kabupaten Semarang tercatat Rp 37.500.000,00 (11\%) disalurkan untuk bea siswa bagi 750 siswa. BAPELURZAM dana ZIS yang disalurkan melalui biaya pendikan (dimasukkan dalam kelompok asnaf ibnu sabil) sejumlah Rp. 2.500.000,00 (3,4 \%). Panitia zakat masjid Shuufi menyalurkan dana zakat malnya sejumlah Rp. 4800.000,00. Penyaluran dana zakat untuk beasiswa oleh BAZIS Kabupaten Semarang diatur dengan peraturan Bupati.

\section{Bantuan Biaya Kesehatan}

Program bantuan biaya kesehatan dapat berupa santunan untuk kesehatan, pelayan medis dan lain-lain. Baziz Kabupaten Semarang melaksanakan program biaya kesehatan di antaranya menyediakan pelayanan mobil ambulan. BAZIS Kota Salatiga memberikan pelayanan Kesehatan berupa pelayanan Mobil Ambulan kepada warga Muslim yang sedang mendapat musibah. Pelayan mobil Ambulan ini baru melayani mengantar jenazah dari rumah duka ke makam dengan tidak di pungut biaya sedikitpun. Sedang untuk luar kota belum dapat dilayani dengan alasan masih terbatasnya biaya operasional. BAPELURZAN memberikan pelayanan kesehatan dalam bentuk pengobatan gratis. Masjid Nurus Sa'adah dengan menggunakan dana infak dan sedekah membukan program pelayanan kesehatan gratis.

4. Bantuan Da'i

Da'i merupakan salah satu bagian dari upaya penegakan agama ( $i$ 'la'i kalimaatillah). Oleh karenanya semua lembaga amil 
zakat yang diteliti memiliki program ini. LAZIM memberikan bantuan kepada para guru TPQ di daerah yang menjadi domainnya setiap guru TPQ memperoleh bantuan Rp. 100.000,00 perbulan. Pada tahun 2009 LAZIM menyalurkan dana ZIS sebesar Rp. 3600.000,00 (3,54\%) untuk 3 orang guru TPQ. BAZIS kota Salatiga di tahun 2009 menyalurkan bantuan Da'i sejulmlah Rp 15.500.000,00 (15,4\%) kepada guru TPQ se kota Salatiga sejumlah 155 orang. BAPELURZAM pada tahun 2006 tercatat Rp. 10.000.000,00 (13,6 \%) disalurkan kepada 40 orang guru TPQ dan Madrasah Diniyah dan Rp. 5.500.000,00 disalurkan kepada 22 orang guru SD/MI. Masjid Shuufi menyalurkan 2.400.000,00 dana infak dan sedekah kepada guru TPQ.

Tabel 1

Distribusi Konsumtif

\begin{tabular}{lccc}
\hline & \multicolumn{3}{c}{ Bentuk Distribusi } \\
Lembaga Zakat & Biaya Hidup & Pendidikan & Kesehatan \\
\hline Lazim & $6,5 \%$ & $70 \%$ & Ada, imsidental \\
BAZ kota Salatiga & $64.6 \%$ & - & Ada, insidental \\
BAZIS Kab. & $76 \%$ & $13 \%$ & - \\
Semarang & $27 \%$ & $3,4 \%$ & Ada, insidental \\
Bappelurzam & \multicolumn{3}{c}{ Sumber: Data terolah }
\end{tabular}

Dari tabel tersebut dapat diketahui bahwa lembaga amil zakat LAZIM yang dikelola di bawah naungan Pimpinan Daerah Muhammadiyah Kota Salatiga dalam pola mendistribusikan dana zakat, infak dan sedekah secara konsumtif yang paling dominan adalah dalam bentuk biaya pendidikan. Sementara tiga lembaga amil zakat yang lain yaitu BAZ kota Salatiga, BAZIS kabupaten Semarang dan BAPELUZAM lebih menekankan pola distribusinya pada penyaluran untuk biaya hidup dengan berbagai macam vareasinya.

\section{Pendistribusian Dana Zakat Yang Bersifat Produktif}

Pendistribusian dana zakat yang bersifat produktif, di lapangan ditemukan dalam bentuk qardlul hasan, mudlarabah dan investasi. Qardlul hasan adalah peminjaman modal usaha dengan mengembalikan pokok tanpa ada tambahan jasa. Mudlarabah 
adalah penanaman modal usaha dengan konsekuensi bagia hasil. LAZIM menyalurkan dana ZIS melalui qardlul hasan pada tahun 2008/2009 sejumlah Rp. 5.200.000,00 (5,1\%) dan melalui mudlarabah sebesar Rp. 14.000.000,00 (13,8 \%) dalam bentuk penggemukan kambing. BAZ kota Salatiga menyalurkan dana ZIS melalui qardlul hasan sejumlah Rp 20.000.000,00 dalam bentuk modal kerja kepada para fakir miskin yang memiki usaha.

BAZIS Kabupaten Semarang menyalurkan dan ZIZ untuk bantuan modal dalam bentuk Qardlul Hasan sebesar Rp. 42.500.000,00 bagi 85 pengusaha kecil. BAPELURZAM menyalurkan dana ZIS melalui program mudlarabah pada tahun 2006 tercatat Rp. 41.664.025,00 dengan perincian sejumlah Rp. 32.084.500,00 di tangan peminjam dan Rp. 9,579.525,00 dalam bentuk kas tunai. Panitia zakat masjid Shuufi sebagaimana dijelaskan bendahara masjid (bapak H. Sulardi) menyalurkan dana ZIS dalam program qardlul hasan di akhir tahun 2009 sejumlah Rp. 6.700.000,00.

Tabel 2

Distribusi Produktif

\begin{tabular}{lccc}
\hline & \multicolumn{3}{c}{ Bentuk Distribusi } \\
Lembaga Zakat & Qardlul Hasan & Mudlarabah & Lain-lain \\
\hline Lazim & $5.1 \%$ & $13,8 \%$ & - \\
BAZ kota Salatiga & $19,9 \%$ & - & - \\
BAZ Kab. Semarang & $13 \%$ & - & - \\
Bappelurzam & $55,7 \%$ & $3,4 \%$ & - \\
\hline
\end{tabular}

Sumber: Data terolah

Memperhatikan tabel di atas dapat disimpulkan bahwa ratarata lembaga zakat dalam distribusi dana zakat, infak dan sedekah secara produktif diarahkan melalui program qardlul hasan dalam bentuk modal usaha yang semua lembaga zakat yang diteliti memiliki program ini. Dalam hal ini lembaga zakat Bapelurzam yang paling dominan menyalurkan dana zakat dalam bentuk modal kerja atau modal usaha. Sementara tiga lembaga zakat yang lain yaitu LAZIM, BAZ dan BAZIS penyaluran zakat dal bentuk modal kerja atau modal usaha masih relatif kecil prosentasenya. Sedang distribusi secara produktif dalam bentuk kerjasama mudlarabah( 
bagi hasil) dan penanaman infestasi rata-rata lembaga zakat yang ada masih sangat terbatas dalam menerapkan program ini, bahkan 50\% lembaga amil zakat yang menjadi obyek penelitian belum memiliki program ini.

Efektifitas Pendistribusian Dana Zakat dan Pemberdayaan Masyarakat

Pola-pola pendistribusian dana ZIS yang dilakukan oleh lembaga, badan dan panitia zakat sebagaimana yang sudah dijelaskan di atas betul-betul dapat berhasil dalam sistem pemberdayaan masyarakat dan dirasakan langsung manfaatnya oleh para mustahiq. Keberhasilan zakat dalam pemberdayaan masyarakat dapat dari aspek-aspek sebagai berikut;

\section{Pemberdayaan Ekonomi}

Pemberdayaan masyarakat dalam bidang ekonomi melalui zakat dapat dilihat dari sistem distribusi atau penyaluran zakat melalui pemberian modal kerja baik dalam bentuk mudlarabah maupun qardlul hasan yang dilakukan oleh Bappelurzam, LAZIM, BAZIS Kabupaten Semarang, Panitia Zakat Masjid Shuufi. Distribusi zakat dengan sistem mudlarabah maupun qardlul hasan memberikan dampak yang cukup signifikan dalam pemberdayaan ekonomi mustahiq yang berasal dari kalangan ekonomi lemah.

Pola pendistribusian yang bersifat produktif tersebut mendapat respon yang sangat baik oleh para mustahiq dan memiliki dampak secara positif dalam peningkatan ekonomi mereka. Penyaluran dana ZIS dalam bentuk kambing yang dilakuan LAZIM misalnya, disambut sangat positif oleh para keluarga mustahiq karena dapat menambah kegiatan usaha perekonomian keluarga, yang semula tidak memiliki kambing, dengan adanya program ini maka setelah ada kambing yang mereka pelihara beranak pinak, mereka dapat memiliki kambing.

Di samping itu progran mudlarabah dan qardlul hasal juga sangat membantu para kaum dlu'afa' dalam modal usaha mereka. Sebelumnya mereka banyak yang terjerat kredit rentenir dengan bunga yang cukup tinggi. Dengan adanya progran mudlarabah dan qardlul hasan ini maka mereka secara pelan-pelan dapat menghindari rentenir. 


\section{Pemberdayaan Sumber Daya Manusia}

Hal itu dapat dilihat, misalnya LAZIM yang secara berkala menyelenggarakan pertemuan pembinaan baik dibidang ketrampilan kerja maupun ke agamaan kepada para mustabiq selalu mendapat respon yang positip. Penyaluran dana ZIS dalam bentuk beasiswa dirasa sangat membantu mengurangi beban bagi para kaum dlu'afa' dalam membayar SPP anak-anak mereka. Dari pihak sekolahpun juga ikut merasakan manfaatnya membantu kelancaran keuangan sekolah. Panitia zakat masjid Shuufi yang setiap menjelang atau awal tahun pelajaran menyalurkan dana ZIS memberi dampak positif yang cukup signifikan, yaitu dapat menambah motivasi dalam mengikuti program-program Takmir seperti pengajian-pengajian, sosial keagamaan dan TPQ. Penyaluran dan ZIS kepada para Da'i, guru TPQ dan madrasah diniyah, tidak hanya yang menerima bantuan saja yang dapat merasakan manfaatnya, tapi masyarakat yang memanfaatkan jasa para da'i, guru TPQ dan madrasah diniyah juga ikut memberikan respon yang positif. Dengan demikian sedikit demi sedikit dan secara pelan tapi pasti, zakat melalui sistem distribusi bantuan beasiswa dan bantuan untuk para Da'i dan Guru TPQ masyarakat dapat terberdayakan dalam peningkatan SDM.

\section{Pemberdayaan 'Amil Zakat}

'Amil zakat baik dalam bentuk BAZ, LAZ maupun badan kepanitiaan di Masjid-masjid dimana anggotanya merupakan bagian dari anggota masyarakat juga tidak luput dari obyek pemberdayaan. Dengan adanya lembaga zakat yang memiliki berbagai program terkait dengan sistem distribusi zakat yang dikelola, mau tidak mau harus memperdayakan anggotanya untuk memberikan berbagai ketrampilan kepada para calon mustabiq. Hal ini perlu dilakukan agar penyaluran dana zakat khususnya yang disalurkan dalam bentuk produktif dapat berdaya guna secara maksimal.

\section{Kesimpulan}

Dari uraian di atas dapat ditarik kesimpulan sebagai berikut; Masyarakat cukup beragam pendapatnya tentang asnaf zakat, namun pada umumnya mereka telah mengacu kepada pendapatpendapat kontemporer merespon terhadap perkembangan zaman. 
Pendapat yang demikian akan sangat mempengaruhi bagaimana Lembaga, badan dan panitia zakat mendistribusikan dana ZIS nya. Pendistribusian dana ZIS yang dilakukan oleh lembaga, badan dan panitia zakat di Jawa Tengah dapat dikelompokkan menjadi dua model yaitu pendistribusian secara konsumtif dan pendistribusian secara produktif. Pendistribusiab secara konsumtif meliputi pemberian biaya hidup, beasiswa pendidikan dan biaya kesehatan. Pendistrbusian secara produktif dilakukan dengan sistem mudlarabah, qardlul hasan dan penanaman investasi. Hanya saja sistem mudlarabah dan penanaman investasi masih sangat terbatas.

Pendistribusian secara konsumtif bersifat jangka pendek dan tidak memiliki dampak perubahan secara positif terhadap pemberdayaan mustahiq baik secara ekonomi maupun secara SDM. Sedang yang memiliki dampak perubahan terhadap pemberdayaan mustahiq adalah pendistribusian yang dilakukan dengan model produktif. Pendistribusian zakat secara produktif terbukti dapat memperdayakan mustahiq dari aspek ekonomi dan SDM.

\section{Daftar Pustaka}

Al-Qurthubi. 1993. al-Jami' Li Akhkam al-Qur'an, jilid 1-8.

Al-Qurthubi, tt., Abkam al-Qur'an, hlm. 113.

Harian Suara Merdeka. 2009. Senin, 31 Agustus.

Isma'il Al-Kahlani, Subh al-Salam, Juz.2

Kahf, Monzer. 1997. The Islamic Economy: Analitical of the Functioning of Islamic System, Canada, t.tp.

Mawardi. 2005. "Strategi Efektifitas Lembaga Zakat" dalam Hukum Islam, Vol. IV No. 2 Desember.

Qadir, Abdurrahman. 1998. Zakat dalam Dimensi Mahdlah dan Sosial.

Qardhawi, Yusuf. 1995. Kiat Islam Mengentaskan Kemiskinan (Terjemahan), Jakarta: Gema Insani.

Rahman, Afzalur. 1995. Economic Doctrins of Islam, alih bahasa Soeroyo dan Nastangin dengan judul" Doktrin Ekonomi Islam Jilid 3, Yogyakarta: Dana Bhakti Wakf.

Yafie, Ali. 1994. Menggagas Fiqh Sosial, Bandung: Mizan. 